\title{
EFL Students’' Difficulties and Needs in Essay Writing
}

\author{
A. Ariyanti ${ }^{1}$, Rinda Fitriana ${ }^{1}$ \\ ${ }^{1}$ Widya Gama Mahakam University. Jl. Wahid Hasyim I No. 28, Samarinda, East Kalimantan. \\ Indonesia
}

\begin{abstract}
Having observed the writing class and EFL students' essays in previous semester, the researchers found that their essay were in poor quality. This situation portrays the fact that writing is a complex skill to learn in English language acquisition. This study is aimed to investigate the difficulties faced by EFL students in essay writing as well as exploring their learning needs to have better quality of English composition. Examining essays and administering open-ended questionnaires were done to 33 students of English Department at Widya Gama Mahakam University, Indonesia, to find students' difficulties in broad-spectrum. In addition, semi-structured interview to the writing lecturer was also conducted to dig his perception related to challenging matters about teaching essay writing. The findings showed that students have major difficulties in grammatical, cohesion and coherence terms. Moreover, minor aspects also had been revealed regarding to students' writing, namely paragraph organization, dictions, and vocabulary misspelling. Considering its complexity in accomplishing essay writing task, the students expected more intense guidance from the lecturer, such as continuous consultation regarding to the lecturer's feedback in their essay draft. The interview result confirmed this issue. The lecturer admitted that limited time and big number of students in one class became his great barriers to improve the quality of the students' essay. These facts drive new challenges for the writing lecturer in two ways; 1) the lecturer should guide students properly by using step-by-step procedures so that the students feel comfortable in writing the essay, and 2) explicit explanation related to the revision given is needed. It is important to note that this issue demands a new and effective teaching essay writing strategy to achieve fruitful outcomes of teaching and learning process especially in essay writing context.
\end{abstract}

\section{Keywords: EFL students; essay writing difficulties; need analysis; lecturer's perception; teaching writing challenges.}

\section{INTRODUCTION}

It is obvious that English is regarded as the mean of communication which has already used worldwide. It can bring us to be a developing country in so many aspects of life such as Malaysia, Singapore, and Brunei Darussalam where English has become their second language. Different case is happened in Indonesia where English is still regarded as a foreign language, so that is why EFL students especially Indonesia students mainly still act as low achievers in English language proficiency in active and passive aspects. Specifically to the passive aspect of English language acquisition, most of EFL students should struggle in doing writing task especially in essay writing. An 
absent use of English in real life situation makes EFL students face many problems in writing [1].

It is true that a lecturer is a key stand point to drive the students to gain an excellent achievement in doing writing task especially in essay writing because "a good teacher teaches, a better teacher explains, and the best teacher inspires" [2]. They also add that a lecturer needs to leave a set of traditional methods and move to a new method to be applied in writing class in order to get his students improved in every aspect in essay writing. In addition, modern techniques and teaching aids are surely very helpful to improve the students' essay writing [3].

Many studies have been conducted in order to explore the EFL students' problems in doing writing task including essays. One of them is Rahmatunisa [4] who found that there are three main problems faced by the EFL students in essay writing, specifically, linguistics, cognitive, and psychological problems. She suggested that the teacher needs to encourage the students' motivation to write an essay as well as providing various supportive writing activities such as peer correction and frequent use of dictionaries. Not only the problems above, cultural and religion aspects also influence the production of the EFL students such as the prohibition in a family where the topic is too sensitive for several certain groups.

Different with Rahmatunisa, Younes and Albalawi [5] found kind of different major problems faced by the students in three ways, namely grammatical, punctuation, and spelling problems. Further findings showed that there are several reasons contribute to students' weaknesses in essay writing based on record of their perspectives. Moreover, another research done by Nyasimi [6] indicated that most of the students were rarely engaged with interactive learning strategies. It happened because teaching writing methods that the lecturers often use were lecturer, question and answer, and demonstration by the teacher instead of touching more on classroom interaction such as group work, peer teaching, and role play.

Moreover, Cheng [7] had a research on teacher and students' problems in writing lesson. The students tend to be passive in the class because they do not feel confident enough to be a peer editor for their friend's essay and hardly revise the feedback from the teacher perfectly. In order to figure out many problems faced by EFL students in essay writing, worth research were also been done. Cheng [7] tried to answer the challenge by applying a new technique to help teacher assessing students' essays with Computer Mediated Communication (CMC), so that the process of essay drafting became easier since the drafts were sent through email between teacher and students. It is shown that technology has helped teacher and students in terms of writing process, from drafting, giving feedback, revising, re-revising, until the final result of writing. It is more efficient and effective because students are able to send their work at time that suitable for them and teacher can revise them at time that suits her/him. Furthermore, another platform of solution also has been researched by Imane [8] who suggests, based on her research findings, that writing activities are better when they are done outside of classroom since fun activities and relaxing atmosphere outdoor can influence students' mood in producing better writing in order to the students' writing improved better. This is what many teachers need to consider in order to build the atmosphere of having fun activities in writing an essay.

There is a great chance of possibility that obstacles in essay writing will discourage students and decrease their motivation in developing [9]. This fact, somehow, has attracted researchers' attention to find a brand new formula to boost the 
students' motivation. However, even though writing is a challenging task for EFL students, people cannot leave aside the fact that to have a good writing ability means a guarantee for having a meaningful communication through text among people [10].

Therefore, the major point to be highlighted in this study is investigating the EFL students' difficulties specifically to college students of Widya Gama Mahakam Samarinda University in accomplishing English compositions. As the continuation of determining the students' problems in essay writing, analysing their needs in how to write a good essay becomes the next element to be examined. In addition, the writing lecturer's view has also been investigated to provide balance findings and suggestions for the students.

In brief, this study aimed to answer the following research questions;

1) What are students' difficulties in writing English composition?

2) What errors are commonly appeared in their essay?

3) What are the writing lecturer's challenges in teaching writing?

\section{LITERATURE REVIEW}

\section{The Process to an Eligible Essay Writing}

To write a good English composition seems never very easy. It requires an ability of assessing a good grammar, imagination and thought, exploring major and supporting ideas, putting them together, revising then final editing [11]. Moreover, Younes and Albalawi [5] point out that writing needs huge effort as well as practicing it in terms of paragraph organization, language use, and mechanics, for the reason that those three aspects are potential in influencing the writing performance such as content and vocabulary including elements of how to formulate ideas, develop and analyse them before displaying the essay writing as a final draft. In addition, essay writing provides students opportunities to build and develop critical thinking, so that students are trained to make their own judgement, decide their writing styles, and pick out scientific diction for their academic writing task [12].

Furthermore, it is important to evaluate students' essay writing based on two categories proposed by Gathumbi and Masembe [13], they are basic and advance skills. In basic skills of writing, they involve the correctness of vocabulary, spelling and punctuation and also well-written handwriting. In addition, for advance skills of writing, they implicate how ideas are connected each other, correct structure used, and content originality.

Students must master the use of language in terms of English language formula where it is related to the production of the essay itself. An essay is a product of academic writing where a writer should combine factual data and compare to existing experts' theories [14]. First language interference does influence student's writing performance. Thus, students whose better English skill can produce better writing than those whose first language interfere a lot [15]. Similarly, Ariyanti also point out that "The biggest challenge is derived from the difference in cultural backgrounds between the students' mother tongue and English, so it is possible to know the production of their writing does not 'sound' well in appropriate culture of English" [16].

To learn writing, the students need to pay full attention to the process below which explains how to write an extremely qualified essay [17]: 
1) Comprehend the concept of the essay - every essay has its own qualification

2) Choose only relevant sources to the essay topic

3) Quote only relevant theory from experts - an ability of paraphrasing and summarizing is needed in advance

4) Combine and compare theories among experts

5) Arrange an appropriate paragraph organization

6) Write introductory, body, and concluding paragraphs

7) Read the essay thoroughly, edit, and rewrite the essay

8) Final writing judgement

Likewise, writing elements proposed by Bailey [18] also become urgent matters to pay attention on:

1) In writing an essay, a writer sometimes need to correlate between two variables such as in cause and effect genre of essay

2) Coherence and cohesion are two sides of a coin which function is to make the flow of ideas make sense and readable as well as having sentences and paragraphs connected to each other

3) In certain kind of essay, which is comparison and contrast, a writer should compare similarities and differences between two objects

4) Definition usually exists in introductory paragraph to explain general ideas of the essay topic

5) In discussion part, a writer combine and compare from two sides of issue then finally refer to only one side

6) A writer had better to provide examples in order to give information to readers as detail as possible related to the topic

7) Summarizing skill is needed to generalize the complexity of essay content

\section{RESEARCH METHODOLOGY}

\section{Research Design}

To explore students' difficulties in writing as well as the lecturer's challenges in teaching writing, the researcher conducted qualitative research for three reasons. First, it intended to comprehend and interpret natural events occurred in lives as an individual or groups [19]. In this setting, this research aims to comprehend students' difficulties in essay writing which occurred in natural events, i.e. teaching and learning process in the classroom. Therefore, the researcher administered open ended questionnaire results in order to reveal students' problems in essay writing [20] and interview the lecturer to gain his perspective on teaching writing challenges.

\section{Research Subject}

The subjects of the research were 33 fourth semester students of English Department at Widya Gama Mahakam University Samarinda, Indonesia and one writing lecturer. The objective of writing course in fourth semester is to enable students to have ability in writing different kinds of essays that will be continued to the next semester course which emphasizing on academic writing. This concern becomes the researcher's consideration to involve the fourth semester students as the research 
subjects. For future implication, the researchers believe that analysing the students' difficulties and needs in learning writing is very important related to the students' work in accomplishing a thesis for their graduation qualification.

\section{Research Instrument}

To gain more complete data, it is important for the researcher to apply several research instruments, namely, interview, questionnaire, and examining records [23]. Specifically, the researchers use the following techniques:

1) Open-ended questionnaires: In this research, the researchers distributed openended questionnaires in order to have factual data regarding with the students' difficulties in learning essay writing as well as to find out what they really want and need to improve their ability in essay writing.

2) Semi-structured interview: Semi-structured interview was conducted to investigate the lecturer's perception regarding challenging matters he faced when teaching the students the essay writing.

3) Examining students' essays: The researchers analysed the students' that she collected from the lecturer to find common errors done by the students.

\section{Data Collecting Techniques and Procedures}

As the research procedure, open ended questionnaire was the first instrument that the researcher used to collect the data. After the students had finished answering the questionnaire, she conducted interview to the lecturer to know his perspective on teaching writing and its challenges. The interview records were then transcribed for analysis. Several students' essays were collected afterward as the supporting data to confirm the questionnaire result.

\section{Data Analysis Techniques}

In qualitative study, the researcher classified sort of data findings and interpreting the data whether in implicit or explicit sides of facts. The meaning-making action can be derived from social event or individual subject which is happened and exist in everyday lives [24].

Specifically, the researchers use qualitative data analysis proposed by Flick which is explained briefly as follows [24]:

1) Rough analysis: Overview of data findings, condensation of the data overviewed, and summaries of the data which have been abridged

2) Detailed analysis: Elaboration and comparison between the data findings and theories from experts as well as previous studies, interpretation to the data that have been elaborated and compared to existing theories

3) Theory generating: Forming statement based on hermeneutic interpretation to the students' difficulties and needs in learning writing.

To analyse the open-ended questionnaire result, the researchers determined the themes to find the classification of students' difficulties of writing. Furthermore, as supporting data, the researcher analysed the students' manuscript by classifying the 
errors appeared. In the same way, the result of interview was also analysed by identifying the challenges that the lecturer encountered.

\section{FINDINGS AND DISCUSSION}

\section{Students' Difficulties in Writing Essay}

As the step of collecting data is done, the open-ended questionnaire result the following graph:

Remarks:

G : Grammar

CC : Cohesion \& Coherence

PO : Paragraph Organization

D : Diction

VM : Vocabulary Misspelling

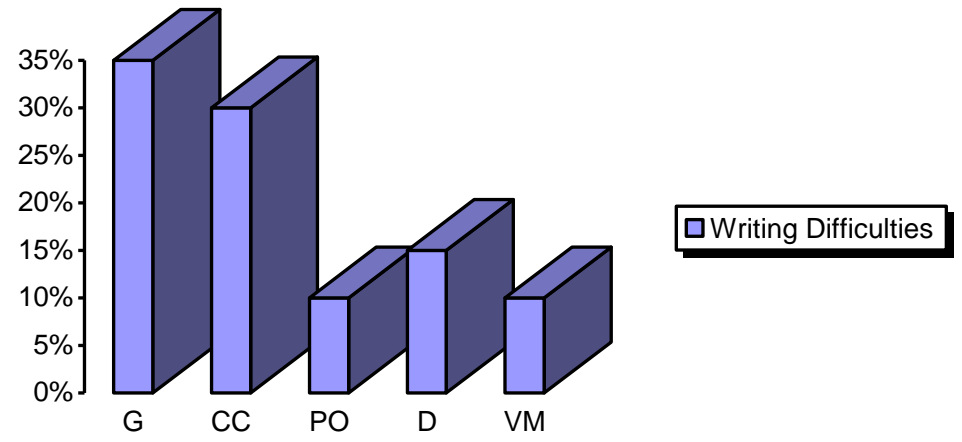

Figure 1. Writing Difficulties Graph Resut

From the chart above, it can be seen that the students' major problems in learning writing are on grammar and cohesion and coherence aspects, followed by diction. Specifically to grammatical terms, on their essay, the researchers found that they frequently missed the use of appropriate tenses, subject-verb agreement, personal pronouns, word order, the use of articles and auxiliary, and sentence fragment.

\section{Errors that Commonly Appeared in Students' Essays}

The following table summarized the grammatical problems found in the ten collected essays. Students commonly did errors on 1) tenses, 2) subject-verb agreement, 3) personal pronoun, 4) word order, 5) article, 6) auxiliary, and 7) sentence fragment. 
TABLE I. THE STUDENTS' GRAMMATICAL PROBLEMS

\begin{tabular}{|c|c|c|}
\hline $\begin{array}{l}\text { Grammati } \\
\text { cal } \\
\text { Problems }\end{array}$ & Extracts from Students' Essays & Suggested Correction \\
\hline \multirow{6}{*}{ Tense } & $\begin{array}{l}\text {.... Samarinda Central Plaza or } \\
\text { people usually called it SCP. }\end{array}$ & $\begin{array}{l}\text {....Samarinda Central Plaza or } \\
\text { People usually call it SCP. }\end{array}$ \\
\hline & $\begin{array}{l}\text {.....because their family did not } \\
\text { often went to mall..... }\end{array}$ & $\begin{array}{l}\text {.....because their family do not often } \\
\text { go to mall..... }\end{array}$ \\
\hline & I was visited Beras Basah Beach. & .....I visited Beras Bash Beach. \\
\hline & $\begin{array}{l}3 \text { years ago, I ever went to Lamaru } \\
\text { beach. }\end{array}$ & 3 years ago, I went to Lamaru beach. \\
\hline & Lamaru beach always became....." & Lamaru beach always become..... \\
\hline & $\begin{array}{l}\text { Last time, I and family spend } 6 \\
\text { hours..... }\end{array}$ & $\begin{array}{l}\text { Last time, I and my family spent } 6 \\
\text { hours..... }\end{array}$ \\
\hline \multirow{5}{*}{$\begin{array}{l}\text { Subject- } \\
\text { verb } \\
\text { agreement }\end{array}$} & It have four floors..... & It has four floors..... \\
\hline & $\begin{array}{l}\text { Today, Samarinda have more } \\
\text { malls... }\end{array}$ & $\begin{array}{l}\text { Today, Samarinda has more } \\
\text { malls..... }\end{array}$ \\
\hline & ..... many game & .....many games \\
\hline & Balikpapan beach have..... & Balikpapan beach has..... \\
\hline & ......an adults & ......an adult \\
\hline \multirow[t]{2}{*}{$\begin{array}{l}\text { Personal } \\
\text { Pronoun }\end{array}$} & $\begin{array}{l}\text { Many people from different ages } \\
\text { often come to } \underline{S C P} \text { because they } \\
\text { have a lot of facilities }\end{array}$ & $\begin{array}{l}\text { Many people from different ages } \\
\text { often come to SCP because it has a } \\
\text { lot of facilities }\end{array}$ \\
\hline & The water make we want to swim & The water make us want to swim \\
\hline \multirow{2}{*}{$\begin{array}{l}\text { Word } \\
\text { order }\end{array}$} & ..... atmosphere cool relax & .....cool and relax atmosphere \\
\hline & ..... beach Balikpapan ..... & .....Balikpapan beach..... \\
\hline \multirow{3}{*}{ Article } & In the middle (...)waterfall..... & In the middle of waterfall..... \\
\hline & Parangtritis beach is a one of... & Parangtritis beach is one of..... \\
\hline & The location (...) this place..... & The location of this place..... \\
\hline \multirow[t]{2}{*}{ Auxiliary } & I'm don't bored to visit it. & I do not feel bored to visit it. \\
\hline & 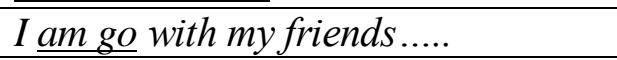 & I go with my friends..... \\
\hline $\begin{array}{l}\text { Sentence } \\
\text { fragment }\end{array}$ & If there is no traffic jam. & $\begin{array}{l}\text { If there is no traffic jam, we can } \\
\text { arrive to the back shortly. }\end{array}$ \\
\hline
\end{tabular}

Related to students' difficulties in writing, the findings of students' errors are in line with the difficulties encountered by students. In regard with coherence problem, the students' biggest problem is on thesis statement. In this case, the students should rely on thesis statement in forming every topic sentence on body paragraphs, but the matter of fact, they did not put it on their introductory paragraph so that the ideas exist in all paragraphs were not connected each other.

Regarding to cohesion problem, the extracts below are sample of what the students wrote on their essays: 
TABLE II. THE STUDENTS' COHESION PROBLEMS

\begin{tabular}{|l|l|}
\hline \multicolumn{1}{|c|}{ Extracts from Students' Essays } & \multicolumn{1}{c|}{ Suggested Correction } \\
\hline $\begin{array}{l}\text { I used to visit a beach called Lamaru. Its } \\
\text { location is in Balikpapan. It takes two } \\
\text { hours and a half to get there from } \\
\text { Samarinda }\end{array}$ & $\begin{array}{l}\text { I used to visit Lamaru Beach which is } \\
\text { located in Balikpapan. It takes two hours } \\
\text { and a half from Samarinda to get there. }\end{array}$ \\
\hline $\begin{array}{l}\text { Kayangan Island is huge, many people } \\
\text { went there }\end{array}$ & $\begin{array}{l}\text { Many people visit Kayangan Island } \\
\text { because of its large area. }\end{array}$ \\
\hline $\begin{array}{l}\text { Until now, I still like swimming, but I } \\
\text { rarely go to the beach, but usually go to } \\
\text { swimming pool }\end{array}$ & $\begin{array}{l}\text { I prefer going to swimming pool to do } \\
\text { myimming hobby instead of to a } \\
\text { beach. }\end{array}$ \\
\hline $\begin{array}{l}\text { The location of this place is at Bantul } \\
\text { regency. It is so far away from my } \\
\text { hometown. It's around two hours to go to } \\
\text { this place }\end{array}$ & $\begin{array}{l}\text { This place is located in Bantul regency } \\
\text { which is quite far from my hometown, } \\
\text { approximately two hours driving. }\end{array}$ \\
\hline
\end{tabular}

Instead of having major problems of grammar and coherence and cohesion, the students also encountered three minor difficulties; paragraph organization, diction, and vocabulary misspelling. Related to paragraph organization, most of the students did not start a paragraph with indented line. In addition, the length of paragraphs they wrote was inappropriate since many students wrote too many sentences that makes the paragraph too long and not readable. On the contrary, some of the students only had one sentence for a paragraph which was not meet required number of sentences in a paragraph, i.e.; five to seven sentences.

Moreover, the next problem is 'diction', wherein, some students have difficulties in choosing correct word for certain sentence context. For example, "dark water", "'clear water", "large tree", "the sand is pure white". In addition, some students used nonacademic words to express their ideas on their academic essay such as the word "thing" which is not considered as academic or scientific word diction. Therefore, it is suggested for the students to use more specific and academic words to express their intention on the sentences they made. Lastly, the students also faced misspelling vocabulary problem that contributes to the low quality of their essay.

The above mistakes made by the students confirm the result of open-ended questionnaire to the students. They definitely said that grammatical aspect is one of the biggest problems they are facing in the writing class. For the students, it is very complicated and difficult to write sentences with correct structure of English. The same case as coherence and cohesion terms, the students simply do not understand the differences between them because the lecturer has never explained it in detail, especially in terms of providing the students with a set of exercises on how to make their essay become coherent and cohesive. To sum up, the students encountered difficulties on both basic and advanced skills of writing as what Gathumbi and Masembe [13] has pointed out in literature review above.

Based on the difficulties faced by the students, the students need advance guidance especially in drafting process where the lecturer distributes the essays to be revised by the students. This writing need makes sense because the students use the feedback from the lecturer as a platform or basis to make improvement in their essay.

In addition, from the lecturer' feedback, the students can obtain revision from the lecturer regarding with what should they add and reduce in their essay content as well 
as what should their revise about their grammar, cohesion, coherence, and paragraph organization [25]. Intensive feedback is considered to be in the top priority in the process of students' essay because it will increase their motivation and they will commit to finish the revision because the lecturer keeps an eye on their writing progress. Hence, by doing this technique, students' confidence to write an English essay will be increased and their writing anxiety will be decreased [26]. It is true because the complex process of producing a qualified writing is starting from content up to grammatical aspects are potential to drive the students to high anxiety level [27]. Therefore, it is important to note that giving feedback is not merely judging whether the students go wrong in writing, but it tends to a matter of guidance and making the students comprehend on how to deal with their misconception.

\section{The Challenges in Teaching Writing (the Lecturer's Perspective)}

The lecturer admitted that he found some challenges regarding to teaching writing. First, he mentioned that the students have limited vocabulary. Moreover, students have low motivation in making composition. He also stated that the students have poor basic knowledge of writing, in terms of sentence structure and grammar. They also have low ability in developing ideas in essay. Regarding to the lecturer's aspect, he admitted that he is lack of creativity of teaching writing.

However, there is eagerness from the lecturer to give intense guidance as well as detail explanation to the students, but he confessed that the lack of time and big number of the students become big challenges for teaching essay writing to the students. In addition, concerning to the problems, the lecturer found it difficult to accommodate the students' problems, even though he had already conducted essay consultation to the students individually on every essay drafting process. The lecturer argued that the disadvantageous classroom condition makes the consultation session did not work, since, the noise from outside the classroom interfered the lecturer's and student's concentration. Other students who are waiting for their turn make a noise in the classroom, therefore it disturbs the lecturer's and student's concentration.

Above explained barriers faced by the lecturer in teaching writing are confirmed by a research from Almubark [28]. Particularly, the lecturer had lack of time allocated to teach writing in the classroom. This barrier results less attention to the students' difficulties since there are overloaded number of students exist in the classroom where each of the student has different kind of problems in essay writing. In other words, further evaluation is needed in order for both the students and lecturer do not encounter above problems continuously.

\section{CONCLUSION AND SUGGESTIONS}

In brief, the fourth semester students of Widya Gama Mahakam University have problems in writing essay, in terms of using correct grammar in sentences, compiling cohesive and coherence paragraphs, and choosing the appropriate diction. The lecturer who taught the subject also confirmed the problems and argued that the allocated time and classroom condition contribute to poor writing performance. Therefore, based on above research findings and discussion toward the students' difficulties and needs in learning writing, as well as considering the problems faced by the lecturer which 
somehow give impacts to the daily teaching and learning process of writing in the classroom, several suggestions are offered to be applied by teachers and institution. Firstly, in order to teach the students better, a sort of training is needed so that the lecturer can have brand new techniques and strategies to teach writing to EFL students. Secondly, additional credits for English writing and grammar courses should be added to have deep understanding from the students. Lastly, reduction of classroom size is important aspect to be highlighted in order to have more effective and satisfied teaching and learning results.

\section{REFERENCES}

[1] U. Salma, "Problems and Practical Needs of Writing Skill in EFL Context: An Analysis of Iranian Students of Aligarh Muslim University," J. Humanit. Soc. Sci., vol. 20, no. 11, 2015.

[2] D. Adas and A. Bakir, "Writing Difficulties and New Solutions: Blended Learning as an Approach to Improve Writing Abilities," Int. J. Humanit. Soc. Sci., vol. 3, no. 9, pp. 254-266, 2013.

[3] C. Z. Javid and M. Umer, "Saudi EFL Learners' Writing Problems: A Move Towards Solution," in Proceeding of the Global Summit on Education, 2014.

[4] W. Rahmatunisa, "Problems Faced by Indonesian EFL Learners in Writing Argumentative Essay," English Rev. J. English Educ., vol. 3, no. 1, 2014.

[5] Z. B. Younes and F. S. Albalawi, "Exploring the Most Common Types of Writing Problems among English Language and Translation Major Sophomore Female Students at Tabuk University," Asian J. Basic Appl. Sci., vol. 3, no. 2, pp. 7-26, 2015.

[6] N. B. Nyasimi, "Challenges Students Face in Learning Essay Writing Skills in English Language in Secondary Schools in Manga District, Nyamira County, Kenya," Kenyatta University, 2014.

[7] M. C. Cheng, "Improving Interaction and Feedback with Computer Mediated Communication in Asian EFL Composition Classes: A Case Study," Taiwan J. TESOL, vol. 4, no. 1, pp. 65-97, 2007.

[8] B. Imane, "Difficulties Encountered by Students in Learning the Productive Skills in EFL Classroom and the Relationship between Speaking and Writing: Case of First Year LMD Students at ABOU Bekr-Belkaid," University of Tlemcen, 2015.

[9] A. M. S. Al-Sawalha and T. V. F. Chow, "The Effects of Proficiency on the Writing Process of Jordanian EFL University Students," Educ. Sci., vol. 3, no. 2, 2012.

[10] T. Mohammad and Z. Hazarika, "Difficulties of Learning EFL in KSA: Writing Skills in Context," Int. J. English Linguist., vol. 6, no. 3, pp. 105-117, 2016.

[11] N. T. A. Kareem, "Difficulties Faced by EFL Students in Writing Composition at the Iraqi Preparatory Schools," Al-Fath J., no. 60, 2014.

[12] M. S. Bakry and H. A. Alsamadani, "Improving the Persuasive Essay Writing of Students of Arabic as a Foreign Language (AFL): Effects of Self-Regulated Strategy Development," in 4th World Conference on Educational Technology Researchers, WCETR, 2014, vol. 182, pp. 89-97.

[13] A. W. Gathumbi and S. C. Masembe, Principles and techniques in language teaching: A text for teacher educators, teachers, and pre-service teachers. Nairobi: The Jomo Kenyatta Foundation, 2005.

[14] A. Ariyanti, "Shaping Students' Writing Skills: The Study of Fundamental Aspects in Mastering Academic Writing," Indones. J. EFL Linguist., vol. 1, no. 1, pp. 63-77, 2016.

[15] D. Grossmann, "Process Approach to Writing," University of Brimingham, 2009.

[16] A. Ariyanti, "The Teaching of EFL Writing in Indonesia," Din. ILMU, vol. 16, no. 2, pp. 263-277, 2016.

[17] S. Bailey, Academic Writing: A Handbook for International Students, 2nd ed. London \& New York: Routledge Taylor \& Francis Group, 2003.

[18] S. Bailey, Academic Writing, a Practical Guide for Studies. London \& New York: Routledge Falmer Taylor \& Francis Group, 2003.

[19] P. Leavy, The Oxford Handbook of Qualitative Research. New York: Oxford University Press, 2014.

[20] S. B. Merriam, Qualitative Research: A Guide to Design and Implementation. San Francisco-CA: Jossey-Bass: A Wiley Imprint, 2009.

[21] R. K. Yin, Qualitative Research from start to finish. New York: The Guildford Press, 2011.

[22] M. B. Miles, A. M. Huberman, and J. Saldana, Qualitative Data Analysis: A Methods Sourcebooks, 
3rd ed. California: SAGE Publications, Inc, 2014.

[23] L. R. M. Gay, G. E, and P. Airasian, Educational Research: Competencies for Analysis and Applications. Columbus: Pearson Merrill Prentice Hall, 2006.

[24] U. Flick, The SAGE Handbook of Qualitative Data Analysis. London: SAGE Publications, Ltd., 2014.

[25] R. Murphy, English Grammar in Use. Cambridge: Cambridge University Press, 2012.

[26] A. K. A. Faraj, "Scaffolding EFL Students' Writing through the Writing Process Approach," J. Educ. Pract., vol. 6, no. 13, pp. 131-141, 2015.

[27] A. Ariyanti, "Foreign Language Anxiety in Academic Writing," Din. ILMU, vol. 17, no. 1, pp. 143$152,2017$.

[28] A. A. Almubark, "Exploring the Problems Faced by the Teachers in Developing English Writing Skills for the Students in Saudi Arabia," Int. J. English Lang. Teach., vol. 4, no. 10, pp. 10-23, 2016. 